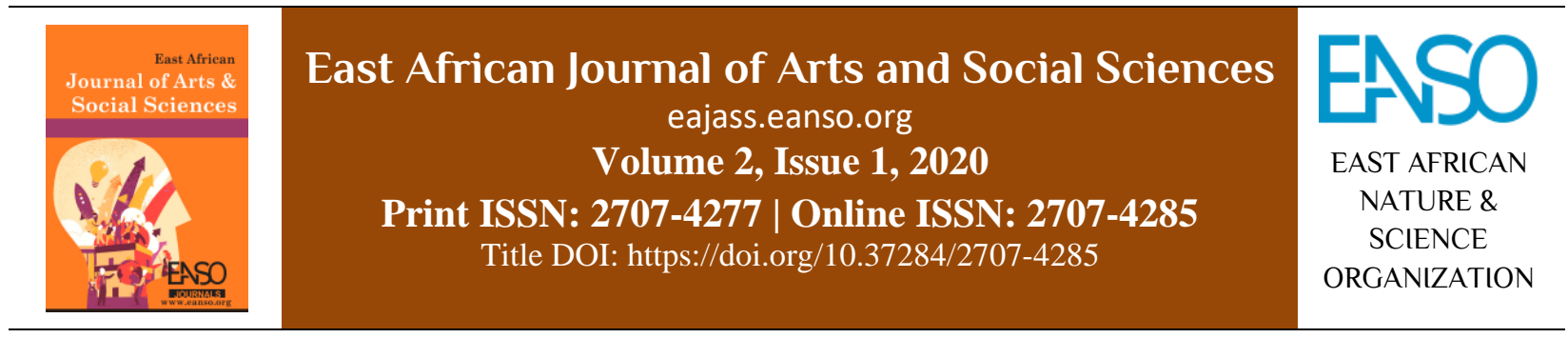

Original Article

\title{
Ascertaining the Influence of Government Dynamics on Juvenile Criminality in Nakuru Sub-County, Kenya
}

\author{
Justus Odongo Kiche \\ Institute of Security Studies, Mount Kenya University; P. O. BOX 342 - 01000, Thika, Kenya. \\ *Correspondence email: odongojustus25@gmail.com.
}

Article DOI: https://doi.org/10.37284/eajass.2.1.128

\section{Article history:}

Received: 13 Mar 2020

Accepted: 23 Mar 2020

Published: 01 Apr 2020

Keywords:

Government Dynamics,

Crime,

Juvenile,

Juvenile Criminality,

Urban,

Nakuru,

Kenya.

\section{ABSTRACT}

The issue of juveniles engaging in criminality is rampant and it is considered as one of the problems and concerns in Nakuru County Kenya. The study focused on ascertaining the influence of government dynamics on juvenile criminality in the Nakuru sub-county, Kenya. The target population was 144 individuals that included 73 police officers from Bondeni police station, 35 juveniles drawn from children remand home, 35 parents/guardians of the said juveniles, and one chief from Bondeni location. The researcher selected a sample size of 102 respondents composed of 62 police officers, 32 juveniles, seven parents/guardians, and one chief. The researcher used a questionnaire and an interview schedule to collect data. The validity of this study was achieved through a thorough consultation with the supervisors and other specialists. Reliability was used to focus on the degree to which empirical indicators are stable and consistent. A Cronbach's coefficient alpha was used to measure the reliability of the research instruments. An alpha coefficient value of 0.7 suggested the instrument is reliable. The study adopted the mixed research methodology and the concurrent triangulation design. Quantitative data were analysed descriptively, while qualitative data was analysed thematically. The study found out that there was a positive association between all the measures of government dynamics and juvenile criminality in Nakuru sub-county. The government dynamics that I focused on included: Government policy, Government support, and Government partnership with other stakeholders. The study concluded that there was an influence of government dynamics and juvenile criminality in Nakuru sub-county, Kenya. The study recommends that the government should make efforts to encourage positive partnerships with other stakeholders in order to reduce juvenile criminality. Therefore, there is a 
need for the juvenile department to improve its policies and expected performance in regard to juvenile criminality.

\begin{abstract}
APA CITATION
Kiche, J. (2020). Ascertaining the Influence of Government Dynamics on Juvenile Criminality in Nakuru Sub-County, Kenya. East African Journal of Arts and Social Sciences, 2(1), 1-7. https://doi.org/10.37284/eajass.2.1.12
\end{abstract}

\title{
CHICAGO CITATION
}

Kiche, Justus. 2020. "Ascertaining the Influence of Government Dynamics on Juvenile Criminality in Nakuru Sub-County, Kenya”. East African Journal of Arts and Social Sciences 2 (1), 1-7. https://doi.org/10.37284/eajass.2.1.128.

\section{HARVARD CITATION}

Kiche, J. (2020) “Ascertaining the Influence of Government Dynamics on Juvenile Criminality in Nakuru Sub-County, Kenya”, East African Journal of Arts and Social Sciences, 2(1), pp. 1-7. doi: 10.37284/eajass.2.1.128.

\section{IEEE CITATION}

J. Kiche, "Ascertaining the Influence of Government Dynamics on Juvenile Criminality in Nakuru Sub-County, Kenya", EAJASS, vol. 2, no. 1, pp. 1-7, Apr. 2020.

\section{MLA CITATION}

Kiche, Justus. "Ascertaining the Influence of Government Dynamics on Juvenile Criminality in Nakuru Sub-County, Kenya". East African Journal of Arts and Social Sciences, Vol. 2, no. 1, Apr. 2020, pp. 1-7, doi:10.37284/eajass.2.1.128.

\section{INTRODUCTION}

Juvenile criminality involves participating in criminal behaviour by a juvenile (Siegel and Welsh, 2011). Juvenile criminality is determined by multiple government dynamics which are typically interrelated in complex ways (Lipsey \& Derzon, 1999; Loeber \& Farrington, 1998). Globally, children aged 10-14 years are considered to be incapable of having knowledge of committing crime in any court hearing (to be Doli Incapax); unable to commit crime (Elizabeth \& Laurence, 2008). For instance, in a case in England, the prosecution demanded to prove beyond reasonable doubt that a juvenile had committed an offence (Newburn, 2002). In Kenya, a study that was done in Kamiti Youth Corrective Training Centre (KYTC) showed that the government dynamics such as lack of government policy, poor government support and lack of government partnership with other stakeholders have been some of the reasons why juvenile criminality is rampant. (Omboto, 2013).

Kenya has eleven Juvenile Remand Homes all of them under the Department of Children's Services. Nakuru County is one of the counties in Kenya that is exposed to the pressures of crime. Several clashes in the county led by the juveniles indicate how they involve themselves in criminal activities (Falcetto,
2012). According to regional crime trend analysis in the police annual crime report (2014), the regions which recorded high crime rates were Nyanza (22\%), North Eastern (18\%), Central (9\%) and Rift Valley (3\%). According to Omboto (2013), minors are not able to distinguish which factors perpetuate their indulgence into criminal activities. They, therefore, get involved in criminal activities without their knowledge. According to Mooney and Young (2006), studies need to be carried out to identify the context and specific factors that promote juvenile involvement in crime. More often than not, parents blame juveniles while the juveniles shift their blame to the errant government policies. In an effort to correct the existing void, the study, therefore, sought to ascertain the influence of government dynamics on juvenile criminality in Nakuru sub-county, Kenya.

The issue of juveniles engaging in delinquencies is a global agenda. Juvenile criminality is considered as one of the major problems and concerns in criminal justice for many countries. This phenomenon is a growing trend in Kenya attributed to various crime prevention programmes lacking enough resources to deal with such a scourge. Juvenile criminality has been well documented by previous records showing those who are killed or those caught committing acts like mugging and murder including records of crime during $2007 / 2008$ general election. This is according to the 
Kenya National Youth Policy (2007). In Kenya, there has been a high rate of juveniles engaging in criminal activities indicated by the high number of children arrested or sentenced due to criminal acts. Tough laws have failed to reduce crime effectively.

There is a paucity of evidence denoting how the government dynamics correlates with the causalities of juvenile criminality. Due to that, it is hard for police officers and other stakeholders that deal with juvenile criminality to coming up with appropriate strategies to combat crime among the juveniles, hence, the need for this study. Therefore, the study is important as it ascertained the influence of government dynamics on juvenile criminality in Nakuru sub-county, Kenya for the purpose of recommending appropriate actions to address the situation. Nakuru County is one of the urban areas in Kenya which are highly populated metropolitan area with mixed ethnic backgrounds. Government dynamics include government policy, government support and government partnership with other stakeholders. The study, therefore, aimed to fill the identified gaps by ascertaining whether government dynamics influenced the likelihood of children engaging in criminal activities in the county.

The research was envisioned to help approve planning and training of parents and teachers on how to detect juvenile criminality. This would prevent maladaptive behaviour and activities that lead them to become criminals. Research may be useful to the security and children departments in understanding the nature of crimes committed by juveniles. The study results also may be useful to the government in developing more effective strategies in dealing with criminal activities among the juveniles. In addition, the study would benefit the general public in understanding the increase in the rate of criminal activities by children.

\section{LITERATURE REVIEW}

\section{Government Dynamics}

Law authorization organizations progressively underline that juvenile's misconduct counteractive action and mediation are key components of network arranged policing. Nonetheless, numerous law authorization offices and network associations do not have the data and assets to mediate successfully in circumstances including energetic wrongdoers. Open wellbeing and counteractive action systems can give far-reaching, directed, network administrations and support to in danger youth. According to Vanderschueren (2000), managing issues related to juvenile gangs is one of the priorities of administration approaches. Its approach is custom-fitted to the particular gathering and individuals. What works best is a blend of care, corrective, instructive and business measures. The administration needs to accomplish more than just set cut-off points by forcing punishments on adolescents who have carried out a wrongdoing. It is likewise imperative to offer youngsters the possibility of work or instruction. This will shield them from setting out on the existence of wrongdoing.

\section{Influence of Government Dynamics on Juvenile Criminality}

According to Vanderschueren (2000), the government is taking the following measures to prevent young offenders from re-offending. Each youngster is extraordinary and merits bolster that is particularly custom fitted to them. For instance, an aggressive individual can be requested to go to a program to figure out how to adapt to and control hostility. The Offending Behaviour Programs Accreditation Committee surveys the courses to decide if they have really had the coveted impact. At the point when a youngster is discharged from youthful guilty parties' foundation, he or she needs to reintegrate into society by going to class or college or finding a vocation.

Institutions overseeing juvenile wrongdoers such as the Child Protection Board, the Youth Probation Service and sub-regions cooperate in the system and process-related consultative bodies. They mastermind, protect, wage, and train as well as work with incarcerated children upon discharge.

According to Vanderschueren (2000), early intercession assumes an essential part in shielding minors from engaging in wrongdoing. Quick and steady discipline for offences can help lessen the rate of wrongdoing.

According to Vanderschueren (2000), at the point when a minor has striven for an offence, the guardians or guardian are required to go to the court 
proceeding with the goal that the judge can get a feeling of the family circumstance and the minor concerned. In the event that the guardians neglect to go to a hearing, the court can issue a warrant to anchor their participation in court. In such cases, the police get the guardians at home and escort them to court. Guardians are likewise required before the trial. The police frequently converse with the guardians while the Child Protection Board likewise sets up contact with them. The Youth Probation Service gets in touch with them after the pre-preliminary detainment arrangement is lifted.

Vanderschueren (2000) notes that young lady scouts, boy troopers, church youth gatherings, and volunteer gatherings all include youth inside a network. Contribution in local gatherings furnishes youth with a chance to connect in a sheltered social condition. Juvenile and youth crime being a worldwide problem, and it being one of the major challenges to sustainable cities, a variety of measures have been suggested and taken into an account. Just as there is no single cause to crime and violence, there is no single solution to the problem. According to Vanderschueren (2000) in UNCHS (United Nations Centre for Human Settlements) document the fight against crime is based on three principles which are law enforcement, solidarity and crime prevention. In law enforcement, suppression of crime by the government organs responsible for maintenance of law and order, law enforcement and decree of other authorities is important.

\section{RESEARCH METHODOLOGY}

Institutional dynamic theory and Juvenile Criminality theory were used. The target population was 144 including police officers, juveniles, parents/guardians, and chief. The researcher selected a sample size of 102 respondents. In achieving the objective of the study, the researcher adopted the mixed approach of research (Tashakkori \& Teddlie, 2003). Mixed method approach is an aspect of both quantitative and qualitative procedures (Creswell, 2003). This method emanates from the conviction that neither quantitative nor qualitative approach is selfsufficient. Concurrent-triangulation design was applied, it is a mixed-method strategy whereby the researcher converged quantitative and qualitative quantitative and qualitative data in order to provide a comprehensive analysis of the research problem (Creswell, 2003). The design explored the in-depth and holistic understanding of the phenomenon. Both quantitative and qualitative approaches were used in data collection by the use of questionnaires and interview schedule. The two approaches were used so that the overall strength of the study is greater than either qualitative or quantitative research as stated by Creswell \& Clark (2007). The researcher used a questionnaire and an interview schedule to collect data. Quantitative data was analysed descriptively and inferentially. Descriptive statistics was analysed using frequencies and percentages and reports presented using tables. Inferential statistics was analysed using Pearson Correlation Coefficient and presented in tables. Qualitative data was analysed thematically and presented in narrative form and quotations.

\section{Research Findings and Discussions}

The study results showed that the overall mean score of influence of government dynamics on juvenile criminality in Nakuru sub-county was 3.27. On government policy, the respondents' opinion on the education and awareness policies practised in different parts of the country on matters concerning juvenile criminality yielded a mean of 3.56 and a SD of 0.475 . Based on the study findings, the government does not support the society by proving funds to the juvenile remand homes as supported by a mean of 3.10 and SD of 0.531 . In relation to the government partnership with other stakeholders to address the challenges of juvenile criminality, a mean of 3.16 and SD of 0.628 were obtained. 
Table 1: Extent to which government dynamics have influenced juvenile criminality

\begin{tabular}{llll}
\hline Statement & N & Mean & Std. Dev \\
\hline $\begin{array}{l}\text { Government policy including education and awareness policies have been } \\
\text { practised in different parts of the country on matters concerning juvenile } \\
\text { criminality }\end{array}$ & 3.56 & .475 \\
$\begin{array}{l}\text { Government supports the society by providing funds to the juvenile remand } \\
\text { homes }\end{array}$ & 62 & 3.10 & .531 \\
$\begin{array}{l}\text { Government partnership with other stakeholders to address the challenges } \\
\text { of juvenile criminality }\end{array}$ & 62 & 3.16 & .628 \\
Overall Mean score & & $\mathbf{3 . 2 7}$ & \\
\hline
\end{tabular}

The study outcome showed a positive correlation between all measures of government dynamics and juvenile criminality in Nakuru sub-county. Government policy and juvenile criminality in Nakuru sub-county had the highest correlation which was statistically significant $(\mathrm{r}=.549, \mathrm{p}<$ $.05)$. Government support with juvenile criminality in Nakuru sub-county had also a positive correlation $r=0.426$. Government partnership with stakeholders and juvenile criminality in Nakuru sub-county were positively, statistically and significantly correlated $(\mathrm{r}=.362, \mathrm{p}<\quad .05)$. According to Chen et al. (2009), there has been increasing research that state that juvenile criminals are directly related to the government dynamics. Further, the correctional facilities and governments should enact policies that will cater to several dynamics so as to help the juvenile criminals identify ways of doing away with their criminal ways (Peng, 2009).

Table 2: Correlation Analysis of Government Dynamics and Juvenile Criminality

\begin{tabular}{lllll}
\hline & $\begin{array}{l}\text { Juvenile } \\
\text { Criminality }\end{array}$ & $\begin{array}{l}\text { Government } \\
\text { policy }\end{array}$ & $\begin{array}{l}\text { Government } \\
\text { support }\end{array}$ & $\begin{array}{l}\text { Government partnership } \\
\text { with stakeholders }\end{array}$ \\
\hline Juvenile Criminality & 1 & & & \\
Government policy & $.549^{*}$ & 1 & & \\
$\begin{array}{l}\text { Government support } \\
\text { Government }\end{array}$ & $.426^{* *}$ & $.682^{* *}$ & 1 & 1 \\
partnership with & $.362^{*}$ & $.724^{*}$ & $.624^{*}$ & \\
stakeholders & & & & \\
\hline
\end{tabular}

\section{Thematic analysis of Qualitative Data}

Qualitative data obtained from the interview were analysed and discussed thematically. The data was used to reinforce the quantitative findings and to elaborate on the concepts obtained. The following section presents a thematic analysis based on the fourth study objective. The study analysed data from parents/guardians and chiefs found out that most of them agreed that government dynamics in regard to juvenile criminality reduces the risk by over $(90 \%)$. For instance, a male parent stated that,

"Government policy on juvenile criminality must often struggle with the appropriate balance of concern over the healthy development of children who violate the law and a public desire to punish criminals. Criminal acts must be suppressed, condemned, and punished. Children who commit criminal acts must be educated and supported in a growth process that should be the objective of government policy for all young people, including young offenders."

Further, the guardians and chief stated that there was access to better technology and systems and periodical optimal staffing. For instance, the chief indicated,

"There is access to better technology and systems. Every outsourced activity comes with new technology. The government should ensure all children are protected against slavery, have 
the right to education and health care services without discrimination" (Chief)

However, guardians disagreed that juveniles comply with regulatory requirements. One guardian said:

"Compliance with regulatory requirements is an evasive issue, however, we try. The government also is not giving standard attention to the issue of juvenile criminality hence increasing the number of crimes committed by them" (A male guardian)

Another guardian commented that,

"The government should collect and document data on juveniles in the system, guide and assist them to prevent criminality or improve the criminal justice system state and ensure that children's acts are followed."

One parent said that,

"The government has failed to create enough schools, they don't have set rules and laws for correcting mistakes done, there are no enough institutions like remand homes and counselling centres, there is also no enough staffs to manage juvenile institutions."

Therefore, juvenile in Kenya do not comply with requirements during economic dynamics. However, guardians revealed that juvenile officers improved efficiency and effectiveness in services and a majority (80\%) of parents/guardians agreed. Guardian 2 stated:

"Most of the outsourced provider delivered their services on time." (A female guardian)

In addition, parents established that providers bring change which is inevitable for management. Parent 7 said that:

"Change is inevitable; with positive change, the management is able to work efficiently", (A male parent).

This implied that through positive change that the management has, then even the juveniles can learn through the same and change their behaviours. Parent 3 said that,
"The government has come up with education facilities like improved schools to educate juveniles to change their behaviour; there are also people who advocate for children's rights."

This means that the government teaches juveniles on issues regarding juvenile criminality and this has changed their behaviour.

\section{CONCLUSIONS AND RECOMMENDATIONS}

The study outcome showed a positive correlation between all measures of government dynamics and juvenile criminality in Nakuru sub-county. Government policy and juvenile criminality in Nakuru sub-county had the highest correlation which was statistically significant. There is a need for juvenile departments to improve their policies and expected performance in regard to juvenile criminality. Providers were not necessarily committed to organization development. The study concludes that juvenile criminality has also intensified in nature, this has been influenced by the availability of small arms in the country. The study also concludes that there are attempts to dissuade the urban juveniles from engaging in juvenile criminality. These have included initiatives such as the community policing initiatives. Although not very effective, there are instances where the public has provided information to police officers regarding juvenile criminality in the areas. However, the study also concludes that there is the challenge of trust between the public and the police.

The results revealed that the main government dynamics such as lack of government policy, poor government support and lack of government partnership with other stakeholders have been some of the reasons why juvenile criminality is rampant. The study concluded that there was an influence of government dynamics on juvenile criminality in Nakuru sub-county, Kenya.

Government policy and juvenile criminality in Nakuru sub-county had the highest correlation which was statistically significant. There is, therefore, need for the juvenile department to improve on their policies and expected performance in regard to juvenile criminality. The study recommends that the following further areas of 
research be undertaken: studies have concentrated on Nakuru sub-county; therefore, the generalization of results to other counties needs to be done with caution in addition to similar studies being done in other Counties. This study did suggest that further studies can be done on the same sub-County but introducing the elements of moderating variables.

\section{REFERENCES}

Creswell, J. W. (1999). Mixed-method research: Introduction and application. In Handbook of educational policy (pp. 455-472). Academic Press.

Elizabeth, S. S. \& Laurence, S. (2008). Rethinking Juvenile Justice. Harvard University Press.

Falcetto, A., (2012). Perceptions of Conservation and Ecotourism in the Nakuru sub-county County, Kenya. Masters Theses \& Specialist Projects Paper 1186. http://digitalcommons.wku.edu/theses/1186

Farrington, D. P. (2000). Adolescent violence: Findings and implications from the Cambridge Study. Violent Children and Adolescents: Asking the Question Why. London: Whurr Publishers.

Loeber, R. \& Stouthamer-Loeber, M. (2006), Family factors as correlates and predictors of juvenile conduct problems and delinquency ', in Crime and Justice: An Annual Review of Research, Volume 7, eds. M. Tonry \& N. Morris, The University of Chicago Press, Chicago.

Mooney, J., \& Young, J. (2006). The decline in crime and the rise of anti-social behaviour. Probation Journal, 53(4), 397-407.

Omboto, J. O., Ondiek, G. O., Odera, O., \& Ayugi, M. E. (2013). Factors influencing youth crime and juvenile delinquency. International Journal of Research in Social Sciences, 1(2), 18-21.

Siegel, J. L. (2002). Juvenile Delinquency with Infotrac: Theory, practices and law. United Nations, Research Report on Juvenile Delinquency.
Siegel, Larry J.; Welsh, Brandon (2011). Juvenile Delinquency: The Core (4th ed.). Belmont, CA: Wadsworth/Cengage Learning. ISBN 0534519326.

UNCHS (1996). The Habitat Agenda, Goals and Principles: Commitments and Global Plan of Action. Proceedings of UNCHS Conference. Istanbul, Turkey, June 1996. 15pp.

UNCHS (1998). Urban Safety and Crime Prevention. Regional Symposium on Urban Poverty in Asia, Proceedings of UNCHS Workshop, Fukuota-Karachi, Pakistan, 27-29 October, 1998. 10pp.

Vanderschueren, F. (2000). The Prevention of Urban Crime. Paper Presented at the Africities Summit, Windhoek, May 2000. pp. 2-14. 